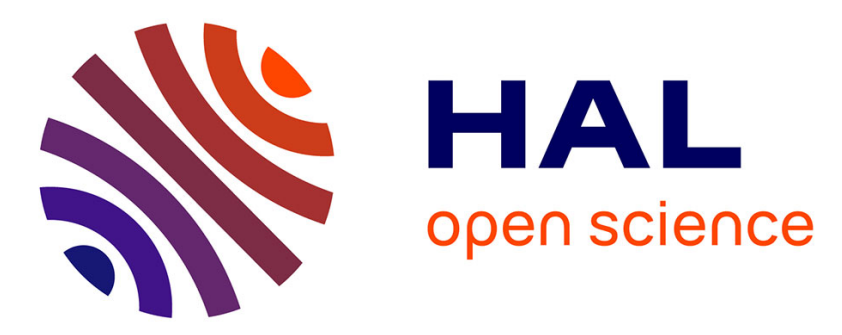

\title{
Amorphous Bi2Pb0.6Sr2Ca2Cu3Ox obtained by melt-spinning and its superconductivity after crystallisation
}

\author{
R. Yavari, P. de Rango, André Sulpice
}

\section{- To cite this version:}

R. Yavari, P. de Rango, André Sulpice. Amorphous Bi2Pb0.6Sr2Ca2Cu3Ox obtained by melt-spinning and its superconductivity after crystallisation. Revue de Physique Appliquée, 1990, 25 (1), pp.9-12. 10.1051/rphysap:019900025010900 . jpa-00246168

\section{HAL Id: jpa-00246168 https://hal.science/jpa-00246168}

Submitted on 1 Jan 1990

HAL is a multi-disciplinary open access archive for the deposit and dissemination of scientific research documents, whether they are published or not. The documents may come from teaching and research institutions in France or abroad, or from public or private research centers.
L'archive ouverte pluridisciplinaire HAL, est destinée au dépôt et à la diffusion de documents scientifiques de niveau recherche, publiés ou non, émanant des établissements d'enseignement et de recherche français ou étrangers, des laboratoires publics ou privés. 
Classification

Physics Abstracts

$74.30-61.40 \mathrm{D}$

\title{
Amorphous $\mathrm{Bi}_{2} \mathrm{~Pb}_{0.6} \mathrm{Sr}_{2} \mathrm{Ca}_{2} \mathrm{Cu}_{3} \mathrm{O}_{x}$ obtained by melt-spinning and its superconductivity after crystallisation
}

\author{
R. Yavari ( $\left.{ }^{1}\right)$, P. De Rango $\left({ }^{2}\right)$ and A. Sulpice ( $\left.{ }^{2}\right)$ \\ (1) LTPCM-CNRS U.A. 29, Institut National Polytechnique de Grenoble, B.P. 75, 38402 St Martin d'Hères, \\ France \\ (2) CRTBT-CNRS, 25 avenue des Martyrs, 38402 Grenoble Cedex, France
}

(Reçu le 28 mai 1989, révisé le 26 septembre 1989, accepté le 9 octobre 1989)

\begin{abstract}
Résumé. - La technique d'amorphisation par trempe d'oxyde fondu a été appliquée aux supraconducteurs à haute $T_{\mathrm{c}}$ de type 2223 à base de bismuth avec addition de plomb. Des échantillons de $\mathrm{Bi}_{2} \mathrm{~Pb}_{0.6} \mathrm{Sr}_{2} \mathrm{Ca}_{2} \mathrm{Cu}_{3} \mathrm{O}_{x}$ amorphe ont été obtenus sous forme de petits fils ou rubans. L'évolution lors de traitement thermique, de cet oxyde amorphe a été suivie par calorimétrie différentielle à balayage (DSC). Une transition vitreuse intervient à $T_{\mathrm{g}}=680 \mathrm{~K}$ et la cristallisation commence à $T=730 \mathrm{~K}$. Après recuit sous oxygène, la susceptibilité magnétique met en évidence deux phases supraconductrices avec $T_{\mathrm{c}}=110 \mathrm{~K}$ et $T_{\mathrm{c}}=75 \mathrm{~K}$ respectivement.

Abstract. - Previous quenching experiments on 2212 bismuth containing high $T_{\mathrm{c}}$ oxides have been extended to the 2223 compound with lead addition. Amorphous $\mathrm{Bi}_{2} \mathrm{~Pb}_{0.6} \mathrm{Sr}_{2} \mathrm{Ca}_{2} \mathrm{Cu}_{3} \mathrm{O}_{x}$ was prepared by a modified meltspinning technique and samples in the form of small tapes and wires were obtained. The subsequent evolution of the amorphous oxide during annealing was monitored by differential scanning calorimetry (DSC). The glass transition was found to occur at $T_{\mathrm{g}}=680 \mathrm{~K}$ and the onset of crystallisation at $T=730 \mathrm{~K}$. After oxygen annealing, magnetic susceptibility measurements showed evidence of two superconducting phases with transition temperatures at $T_{\mathrm{c}}=110 \mathrm{~K}$ and $T_{\mathrm{c}}=75 \mathrm{~K}$ respectively.
\end{abstract}

\section{Introduction.}

There are now several well known techniques for the preparation of high $T_{\mathrm{c}}$ oxide superconductors. We have used rapid solidification to prepare precursors of high $T_{\mathrm{c}}$ superconductors directly from the liquid state thus fixing their shape in a low porosity state. Three different improvements may become accessible via rapid solidification: a) the shaping of the brittle product; b) the achievement of high den-

homogeneous liquid state is a prerequisite for homogeneity after solidification and careful attention is needed when the liquid state contains immiscible elements. Yurek et al. [1] have reported the preparation of high $T_{\mathrm{c}}$ ceramics via oxidation of crushed alloy ingots but this technique does not present the possible potential improvements cited for rapid solidification and appears to produce heterogeneous (multiphase) oxides.

When the liquid alloy of composition corresponding to the metallic components of the superconduct- ing oxides is homogeneous, it can be liquidquenched to an amorphous or microcrystalline state usually in the shape of a ribbon. The ribbon can subsequently be oxidized at appropriate temperatures to obtain the oxide superconductor in ribbon shape [2]. Liquid $\mathrm{Y}_{1} \mathrm{Ba}_{2} \mathrm{Cu}_{3}$ phase-separates due to unmixing tendency between $\mathrm{Y}$ and $\mathrm{Ba}$. But we and others [3-6] have shown that the technique consisting of rapid solidification of the alloy followed by of $\mathrm{Eu}_{1} \mathrm{Ba}_{2} \mathrm{Cu}_{3} \mathrm{O}_{x}$ and $\mathrm{Yb}_{1} \mathrm{Ba}_{2} \mathrm{Cu}_{3} \mathrm{O}_{x}$.

Like the $\mathrm{YBaCu}$ alloys, $\mathrm{BiCu}$ and $\mathrm{PbCu}$ containing alloys also tend to phase separate. In such cases a second technique consisting of the rapid quenching of the oxide melt is applicable as demonstrated by Kim et al. [7] for the $\mathrm{Y}_{1} \mathrm{Ba}_{2} \mathrm{Cu}_{3} \mathrm{O}_{x}$ system and by us and others [8-14] for the $\mathrm{Bi}_{2} \mathrm{Sr}_{2} \mathrm{Ca}_{1} \mathrm{Cu}_{2} \mathrm{O}_{x}$ system. In the latter case, we found that the oxide melt is an easy glass former. In this work, we extend the application of this technique to $\mathrm{Bi}_{2} \mathrm{Sr}_{2} \mathrm{Ca}_{2} \mathrm{Cu}_{3} \mathrm{O}_{x}$ to which 0.6 moles of $\mathrm{PbO}$ were added. 


\section{Experimental results and discussion.}

Oxide powders of $\mathrm{Bi}, \mathrm{Ca}, \mathrm{Cu}$ and $\mathrm{Pb}$ and $\mathrm{SrCo}_{3}$ were mixed to obtain a nominal composition of metal components corresponding to $\mathrm{Bi}_{2} \mathrm{~Pb}_{0.6} \mathrm{Sr}_{2} \mathrm{Ca}_{2} \mathrm{Cu}_{3} \mathrm{O}_{x}$ and calcinated for diffusive mixing. The resulting black powder was molten and melt spun from $T \sim 1425 \mathrm{~K}$ on a copper wheel in air at a substrats speed of about $10 \mathrm{~m} / \mathrm{s}$. Depending on the oxide melt temperature and substrate preparation, solidified samples took wire like forms with cylindrical cross section or ribbon shapes. The present castings were obtained in a closed chamber and broke into 1 to $2 \mathrm{~cm}$ long pieces upon collision with the chamber walls. Nevertheless they allow the conclusion that long oxide ribbons of constant shape can be obtained under optimum conditions. Abe et

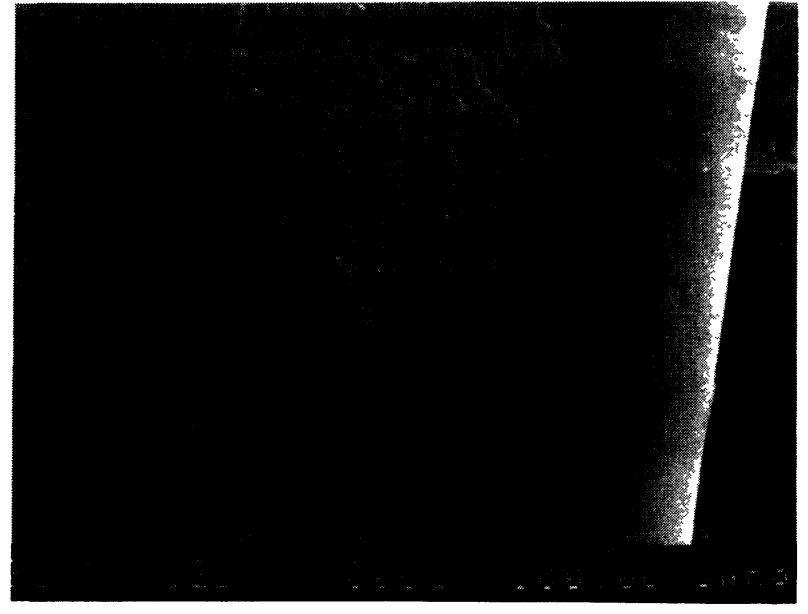

Fig. 1. - Amorphous $\mathrm{Bi}_{2} \mathrm{~Pb}_{0.6} \mathrm{Sr}_{2} \mathrm{Ca}_{2} \mathrm{Cu}_{3} \mathrm{O}_{x}$ ribbon.

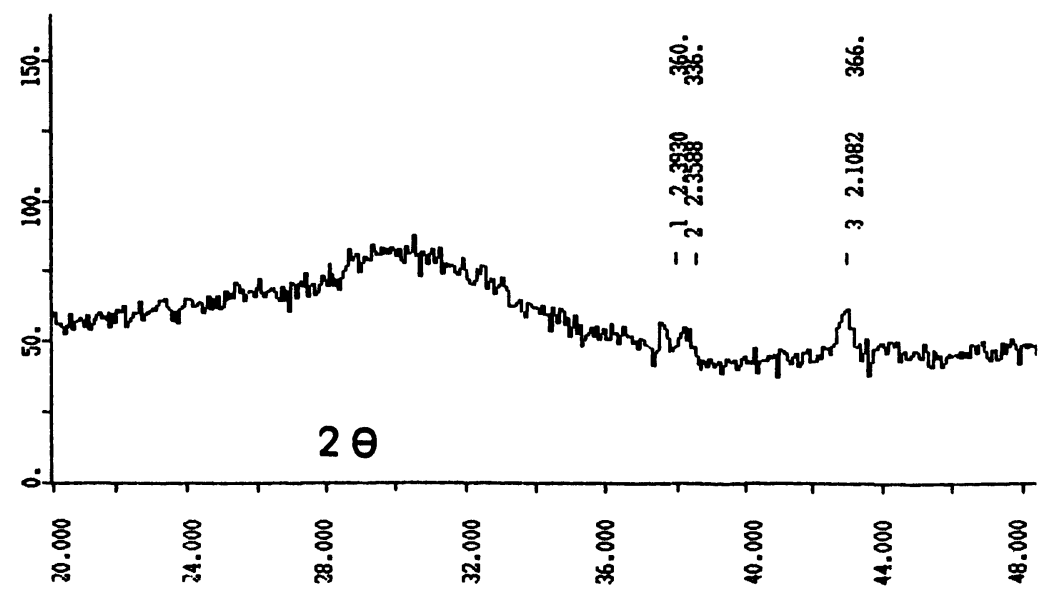

Fig. 2. $-\mathrm{X}$-ray diffraction pattern of melt-spun $\mathrm{Bi}_{2} \mathrm{~Pb}_{0.6} \mathrm{Sr}_{2} \mathrm{Ca}_{2} \mathrm{Cu}_{3} \mathrm{O}_{x}$.

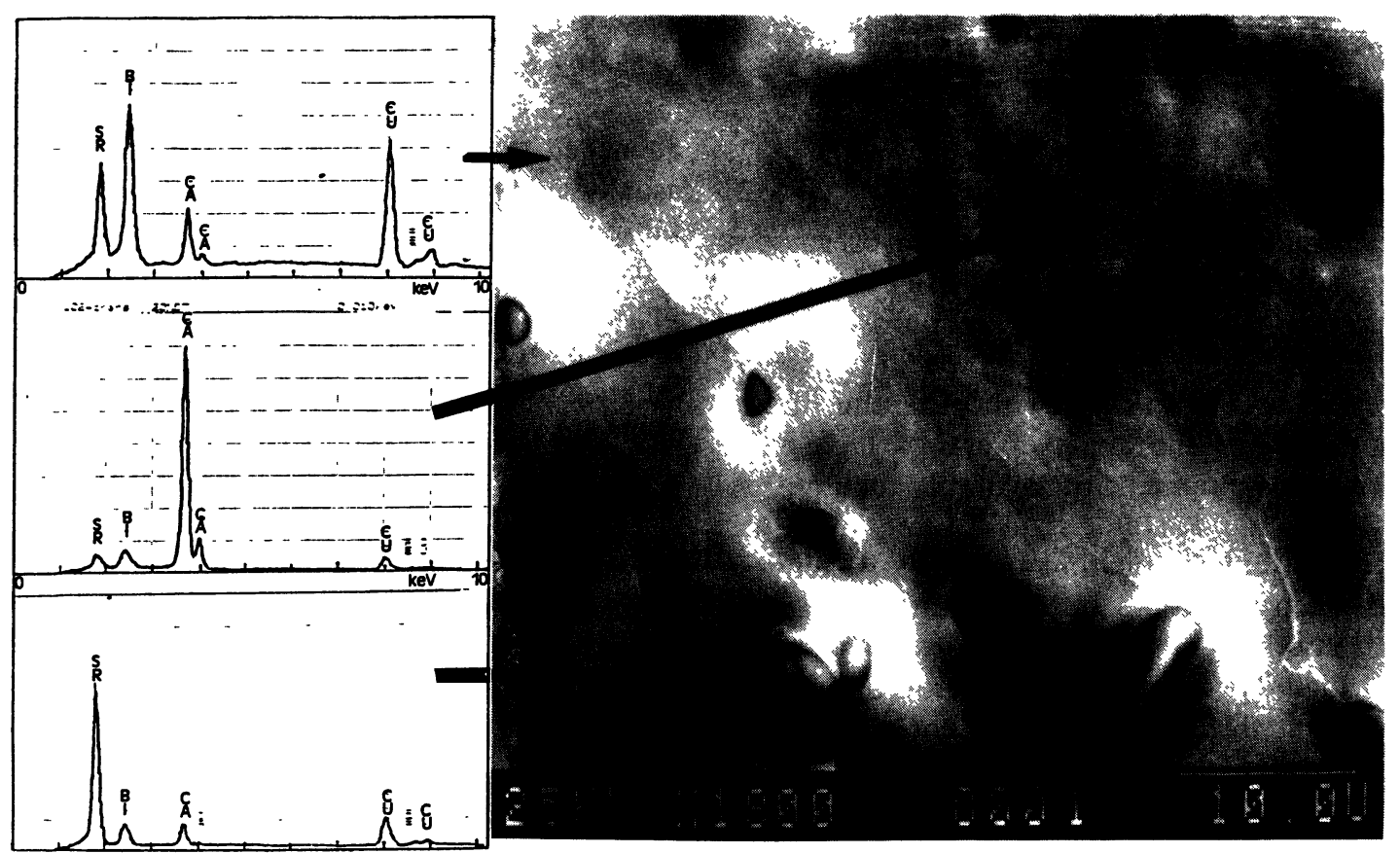

Fig. 3. - SEM secondary electron image of sample of figure 2 showing amorphous matrix and $\mathrm{Ca}$ and $\mathrm{Sr}$ rich precipitates. 


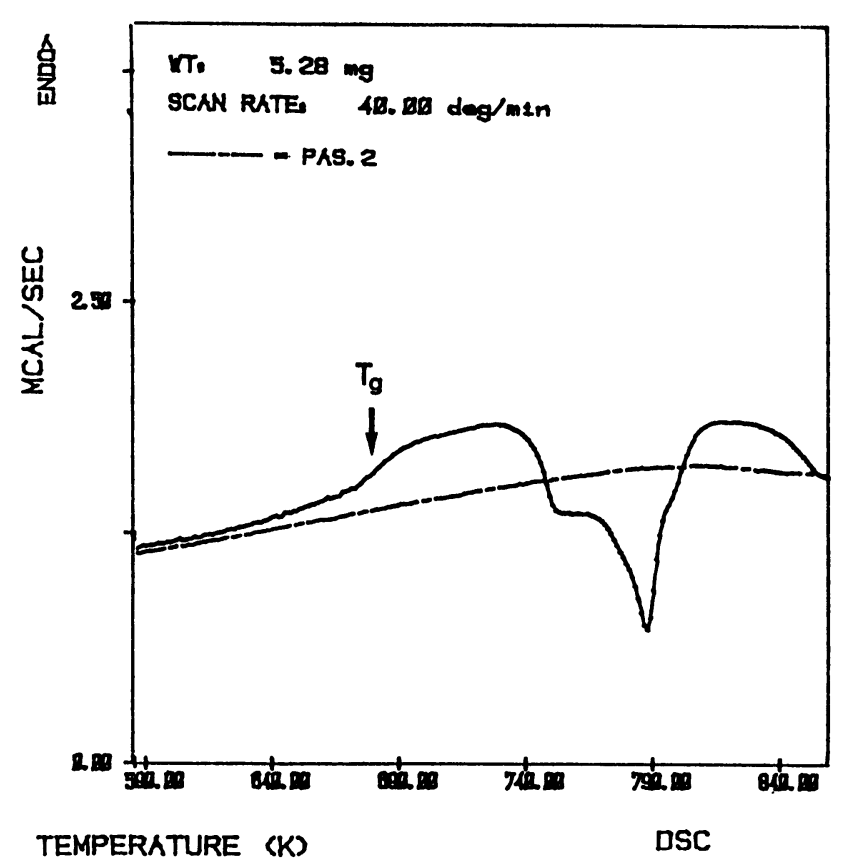

Fig. 4. - DSC thermogram of sample of figures 2 and 3 showing glass transition at $T_{\mathrm{g}} \sim 680 \mathrm{~K}$ and crystallisation at $T>730 \mathrm{~K}$.

al. [15] have previously obtained $\mathrm{BiCaSrCuO}$ rods via the liquid state using a lower quench rate.

Figure 1 shows the substrate-side SEM micrograph of a ribbon segment. X-ray diffraction pattern taken on this sample with a copper tube (wavelength $1.54 \AA$ ) showed the typical principal amorphous halo with traces of crystallinity of an unknown phase (Fig. 2). The SEM micrograph of figure 3 shows a secondary electron image of the amorphous bulk of a sample (this view is from a freely solidified side of a fairly thick sample). Amidst the glassy bulk that appears clear, one notes large grey and darker and smaller diffuse particles. These particles which are likely to be at the origin of the weak Bragg peaks of figure 1 were found to be respectively predominantly calcium and strontrium oxide derivatives as can be seen on the X-ray microanalysis peaks of figure 3 . (The $\mathrm{Pb}$ peak is covered by that of $\mathrm{Bi}$ ). The oxide nature is deduced from their darker colors indicating their low electron density. Such precipitation of Carich and Sr-rich oxides, during quenching would be important thermodynamic indications for the study of the phase diagram in the liquidus region of composition $\mathrm{Bi}_{2} \mathrm{~Pb}_{0.6} \mathrm{Sr}_{2} \mathrm{Ca}_{2} \mathrm{Cu}_{3} \mathrm{O}_{x}$ but require crystallographic (TEM) confirmation.

Differential scanning calorimetry (DSC) also showed the rapidly quenched oxide to be glassy with marked glass transition temperature $T_{\mathrm{g}} \sim 680 \mathrm{~K}$ and crystallisation beginning at $\sim 730 \mathrm{~K}$ for a heating rate of $40 \mathrm{~K} / \mathrm{min}$ (see Fig. 4). The glassy oxide was then annealed at $\sim 1100 \mathrm{~K}$ under oxygen partial pressure.

Figure 5a shows a low magnification SEM micrograph of a wire like segment after such annealing. Figure $5 \mathrm{~b}$ shows the microstructure of this sample at higher magnification: it can be seen that the amorphous featureless phase of figure 3 has been replaced by a crystalline phase with a predominant morphology of very anisotropic plate-like shapes of submicron thickness and diameters greater than $10 \mu \mathrm{m}$ similar but more anisotropic than those previously observed to appear in the $\mathrm{Pb}$-free 2212 tetragonal bismuth oxide $[9,16]$.

The appearance of these plates corresponds to the appearance of superconductivity as previously reported by resistivity measurements [9].

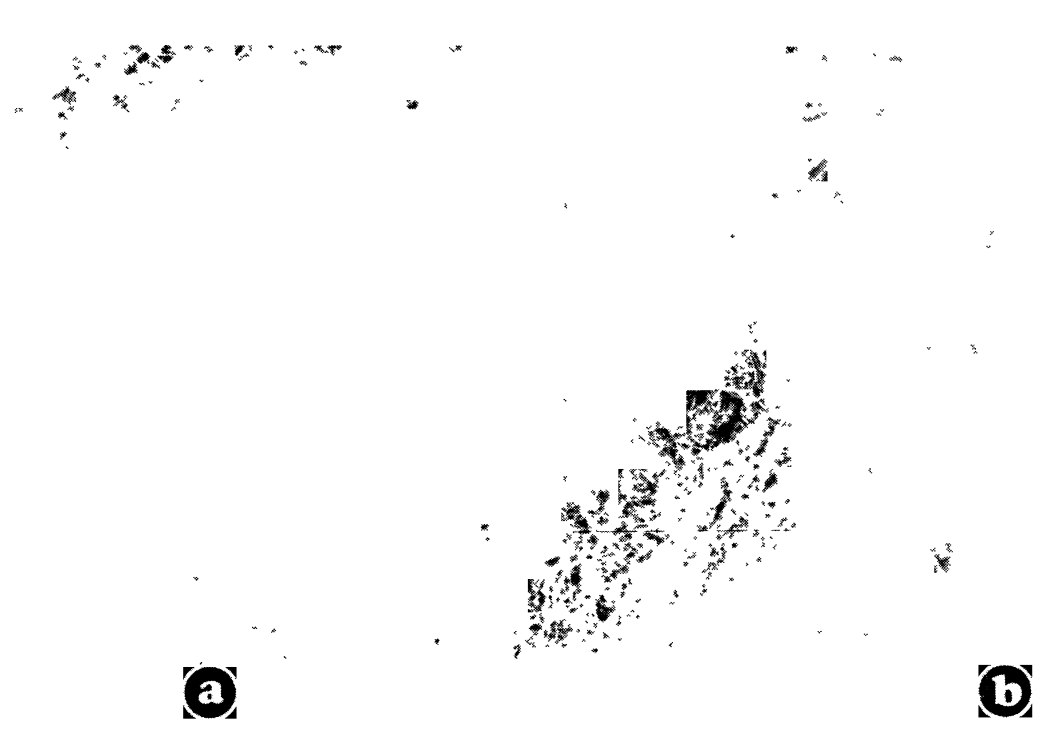

Fig. 5. - (a) SEM image of $\mathrm{Bi}_{2} \mathrm{~Pb}_{0.6} \mathrm{Sr}_{2} \mathrm{Ca}_{2} \mathrm{Cu}_{3} \mathrm{O}_{x}$ melt-spun wire-like sample after oxygen annealing at $T \sim 1100 \mathrm{~K}$. (b) Higher magnification details showing thin plate-like crystals of superconducting phase. 
Figure 6 shows d.c. magnetic susceptibility measured as a function of temperature on an annealed sample. Two transitions are clearly detected at $T \sim 107 \mathrm{~K}$ and $T \sim 77 \mathrm{~K}$ corresponding to the socalled $110 \mathrm{~K}$ and $80 \mathrm{~K}$ superconducting phases. $\mathrm{X}$ ray diffraotion patterns confirmed the two phase nature of the sample with the $110 \mathrm{~K}$ superconductor increasing its volume-fraction with increasing an-

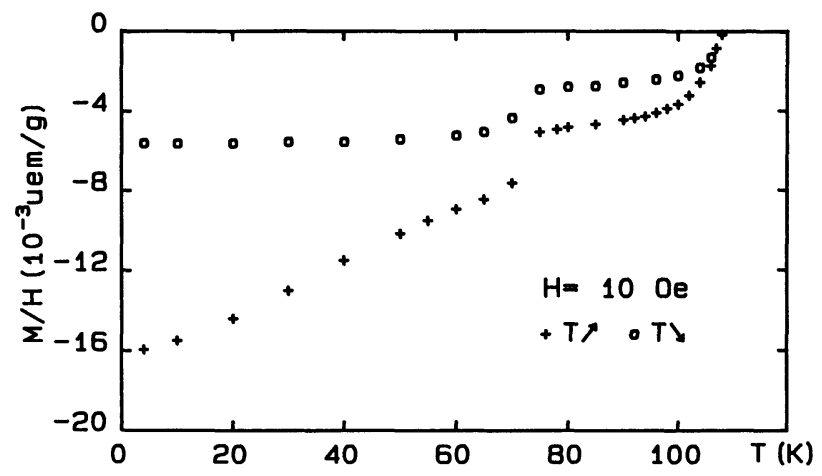

Fig. 6. - Susceptibility versus temperature for melt-spun $\mathrm{Bi}_{2} \mathrm{~Pb}_{0.6} \mathrm{Sr}_{2} \mathrm{Ca}_{2} \mathrm{Cu}_{3} \mathrm{O}_{x}$ after oxygen annealing showing transitions $T_{\mathrm{c}}$ at 107 and $77 \mathrm{~K}$. nealing time [17]. It is expected that oxygen diffusion into these samples which have little or no porosity is slower and requires much longer annealing times for optimisation of the superconducting properties of the 2223 phase.

\section{Conclusion.}

We have found that addition of $\mathrm{Pb}$ to $\mathrm{Bi}_{2} \mathrm{Sr}_{2} \mathrm{Ca}_{2} \mathrm{Cu}_{3} \mathrm{O}_{x}$ oxides increases their glass formability via melt-spinning. $T_{\mathrm{g}}$ is about $680 \mathrm{~K}$, crystallisation occurs some 50 above $T_{\mathrm{g}}$ and the heat of crystallisation is of the order of that measured for metallic glasses ( 1 to $2 \mathrm{kCal} / \mathrm{gm}$.at). High $T$ annealing results in the formation of the tetragonal superconducting phase with $T_{\mathrm{c}} \sim 110 \mathrm{~K}$ but long annealing times are required to reach optimum superconductivity inside the samples. A detailed study of evolution with annealing, of the superconducting volume-fraction and phase distribution is now in progress [17]. It was found that melt-spinning is a viable technique for preparation of these oxide compositions in ribbon form but the experimental set-up has to be optimised to avoid high stresses and shocks below $T_{\mathrm{g}}$.

\section{References}

[1] Yurek G. J., Van der Sande J. B., Wang W. X., RudMan D. A., Zhang Y. and MATthiesen M. M., Metall. Trans. 18A (1987) 1813.

[2] Matsuzaki K., Inoue A., Kimura H., Moroishi K. and Masumoto T., Jpn Appl. Phys. 26 (1987) L3 34.

[3] YAVARI R. and WeIss F., Europhys. Lett. 4 (1987) 1315.

[4] Weiss F., Yavari R., Rouault A., Madar R., Senateur J. P., DesRe P., High $T_{\mathrm{c}}$ superconductors, Interlaken (mars 1988).

[5] Haldar R., Lu Y.Z. and Giessen B. C., Appl. Phys. Lett. 51 (1987) 538.

[6] Matsuzaki K., Inoue A., Kimura H., Aoki K. and Masumoto T., Jpn J. Appl. Phys. 26 (1987) L1310.

[7] Kim N. K., Drozdyk L., Payne D., Friedman T., Wright W. H. and GinsBerg D. M., Mater. Lett. 5 (1987) 387.

[8] Hinks D. G., Soderholm L., Capone D. W., DaBROWSKi B., Mitchell A. W., Shi D., Appl. Phys. Lett. 53 (1988) 423.
[9] Yavari R. and Lejay P., J. Crystal Growth 91 (1988) 290.

[10] Skumryev V., Puzniak R., Karpe N., Zheng-He H., Pont M., Medelius H., Chen D. and Rao K. V., Physica C 152 (1988) 315.

[11] Komatsu T., Sato R., Imai K., Matusita K. and Yamashita T., Jpn J. Appl. Phys. 27 (1988) L1839.

[12] Zheng H. and Mackenzie J. D., Phys. Rev. B 38 (1988) 7166.

[13] Nishi Y., Moriya S. and Manabe T., J. Appl. Phys. 65 (1989) 2389.

[14] Komatsu T., Sato R. and Matusita K., Appl. Phys. Lett. 54 (1989) 1169.

[15] Abe Y., Hosono H., Hosoe M., Iwase J. and Kubo Y., Appl. Phys. Lett. 53 (1988) 1341.

[16] Yavari R., Mém. Sci. Revue Métall. 9 (1988) 452.

[17] De Rango P., Sulpice A. and Yavari R., to be published. 